\title{
The effect of meta-halloysite on alkali-aggregate reaction in concrete
}

\author{
J. Zapała-Sławeta
}

Received: 2 June 2017/Accepted: 19 August 2017/Published online: 30 August 2017

(C) The Author(s) 2017. This article is an open access publication

\begin{abstract}
Damage to concrete structures may occur as a result of internal effects. Alkali silica reaction (ASR) is a long term reaction between alkalis and reactive aggregate present in the concrete. The reaction product is sodium-potasium-calcium silica gel, able to absorb water, resulting in the expansion and cracking of concrete. The key problem is to find the right method for mitigating the internal damage. This paper presents the results of an investigation into the effectiveness of calcined halloysite (meta-halloysite) in improving the resistance to alkali-silica reaction (ASR). The pozzolanic reactivity of meta-halloysite was also evaluated using Thermo-Gravimetric Analysis. Microstructures of mortar bars were observed by Scanning Electron Microscopy coupled with Energy Dispersive X-ray Spectroscopy (EDS) to investigate the location and chemical composition of ASR gel. The results from this study showed satisfactory level of pozzolanic reactivity when cement was partially replaced by meta-halloysite. It was demonstrated that a $20 \%$ addition of metahalloysite are able to mitigate ASR and lower expansion of mortar bars with reactive aggregate to a safe level of not more than $0.1 \%$ at 14 days. Microstructural observations of the specimens containing meta-halloysite indicated the presence of a calcium-alkali-silicate-
\end{abstract}

J. Zapała-Sławeta ( $\square$ )

Faculty of Civil Engineering and Architecture, Kielce

University of Technology, Al. 1000-lecia P.P.7,

25-314 Kielce, Poland

e-mail: jzapala@tu.kielce.pl hydrate gel. But fewer reaction products and with different composition than those forming in the pastes without mineral additives are present.

Keywords Alkali silica reaction - Meta-halloysite . Pozzolanic reactivity $\cdot$ Mortar expansion · Mitigation · Microstructure

\section{Introduction}

Alkali-silica reaction is the deleterious reaction between amorphous or poorly crystallized silica phase from aggregates and alkaline pore solution of concrete. The reaction produces sodium potassium calcium silicate hydrate gels, which swell with water absorption and cause cracking and deterioration of concrete [1, 2].

Different methods exist to mitigate alkali-silica reaction. Many researchers have shown that some chemical admixtures e.g. lithium compounds and supplementary cementitious materials (SCM) such as silica fume, metakaolin, blast furnace slag, fly ashes, zeolite, glass powder, ground clay brick can be used successfully to minimise the effect of ASR [3-14]. It is known that mineral additions having pozzolanic properties are capable of reducing the ASR-induced expansion. Aggregate alkali-reactivity in concrete can be mitigated by replacing part of Portland cement with pozzolanic material, with the net efficacy depending on dosage as well as particular properties [15]. 
Some researchers point to higher effectiveness of mineral addition containing more aluminium relative to pure silica content, e.g., metakaolin [16-18]. The soluble alumina in SCM can reduce the dissolution of reactive silica thus mitigating the ASR. Calcium silicate hydrate phase containing aluminium $(\mathrm{C}-\mathrm{A}-\mathrm{S}-$ $\mathrm{H}$ ) has higher potential to alkali fixing compared to $\mathrm{C}-$ S-H gel, as was demonstrated by Hong and Glasser [19]. Although Hopital and co-workers just as Chappex and Scrivener, Bach and co-workers indicate no significant differences in alkali uptake between $\mathrm{C}$ S-H and C-A-S-H phases [20-22].

Meta-halloysite is formed as a result of thermal activation of halloysite at the temperature range of 500-900 ${ }^{\circ} \mathrm{C}$ as a consequence of dehydration and dehydroxylation of halloysite. Halloysite is a mineral defined as a hydrated phase of kaolinite, composed of kaolinite layers randomly shifted in the $a$ and $b$ directions (a,b-unit cell parameters), which have a tendency for pilling up randomly. The basic unit of the 1:1 halloysite structure consists of tetrahedral and octahedral sheets with the formula $\mathrm{Al}_{2} \mathrm{Si}_{2} \mathrm{O}_{5}(\mathrm{OH})_{4}$. The structure contains water molecules in the interlayer, which makes halloysite distinct from kaolinite. The thermally modified structure is characterised by higher porosity and presence of reactive acid centres resulting from the presence of aluminium, with coordination number 4 and 5 [23-25].

This paper describes the inhibitory role of metahalloysite in ASR and the minimum meta-halloysite content capable of mitigating the ASR distress. The pozzolanic reactivity of meta-halloysite was also evaluated. The mortar bar test results were studied in relation to the microstructural observations under a scanning electron microscope (SEM) and the reaction products compositions was obtained from the energy dispersive X-ray spectroscopy (EDS) to better understand the experimental results. The microstructure and composition of $\mathrm{C}-\mathrm{S}-\mathrm{H}$ and alkali-silica gels that formed in the control specimens and in the metahalloysite-modified specimens were also compared.

\section{Materials}

\subsection{Cement}

In this study Portland cement CEM I 42.5R with alkali content of $\mathrm{Na}_{2} \mathrm{O}_{\mathrm{e}}=0.79 \%$ and specific surface area of $325 \mathrm{~m}^{2} / \mathrm{kg}$ was used. The chemical composition of the cement as determined through X-ray fluorescence spectroscopy is given in Table 1 .

\subsection{Meta-halloysite}

Meta-halloysite was obtained by dehydroxylation of halloysite-10 $\AA$ (composition formula $\mathrm{Al}_{2} \mathrm{Si}_{2} \mathrm{O}_{5}[\mathrm{OH}]_{4}$ $2 \mathrm{H}_{2} \mathrm{O}$ ), from the Dunino mine, near Legnica in Poland. Thermal activation of halloysite was conducted for $2 \mathrm{~h}, T=750{ }^{\circ} \mathrm{C}$. Table 1 shows the chemical composition of meta-halloysite. A study of the particle size of meta-halloysite was carried out using a HELOS KR laser diffractometer. The average particle size of this powder was found to be $3.09 \mu \mathrm{m}$. The particle size distribution curve for meta-halloysite is given in Fig. 1.

\subsection{Reactive aggregate}

Crushed opal aggregate with specific gravity of 2.25 and BET surface area of $5.0 \mathrm{~m}^{2} / \mathrm{g}$ was used as reactive silica aggregate. In the experiment, opal aggregate was used with grain size distribution $0.5-1 \mathrm{~mm}$ in the quantity of $6 \%$ in relation to the mass of standard quartz sand. The microscopic analysis of aggregate thin cuts was performed under an optical microscope with light transmission (OLYMPUS BX51). The mineralogical composition of reactive aggregate is shown in Table 2.

\subsection{Mixture proportion}

Mortar bars containing 0-20\% meta-halloysite as Portland cement replacement by weight were prepared. Table 3 shows the proportions of constituents in specimens for ASTM C1260 and ASTM C1567 tests.

\section{Experimental test methods}

\subsection{Accelerated mortar bar test}

Reactivity potential of the opal aggregate and the effectiveness of meta-halloysite were determined by measuring linear changes in mortars tested according to ASTM C 1260 [26] and ASTM C1567 [27]. Five $25 \times 25 \times 250 \mathrm{~mm}$ bars were made for each test 
Table 1 Chemical composition of cement and meta-halloysite

\begin{tabular}{lcccccccccccccc}
\hline Material & $\mathrm{SiO}_{2}$ & $\mathrm{Al}_{2} \mathrm{O}_{3}$ & $\mathrm{Fe}_{2} \mathrm{O}_{3}$ & $\mathrm{CaO}$ & $\mathrm{MgO}$ & $\mathrm{SO}_{3}$ & $\mathrm{~K}_{2} \mathrm{O}$ & $\mathrm{Na}_{2} \mathrm{O}$ & $\mathrm{TiO}_{2}$ & $\mathrm{MnO}_{2}$ & $\mathrm{P}_{2} \mathrm{O}_{5}$ & $\mathrm{Na}_{2} \mathrm{O}_{\mathrm{e}}$ & $\mathrm{LOI}$ & $\mathrm{N}_{2 . s . p}$ \\
\hline Cement & 18.47 & 5.40 & 2.96 & 63.35 & 1.42 & 3.34 & 0.93 & 0.18 & 0.45 & - & - & 0.79 & 3.00 & 1.00 \\
Meta-halloysite & 49.60 & 41.54 & 5.66 & 0.25 & 0.06 & - & 0.063 & 0.08 & 1.98 & 0.046 & 0.79 & 0.12 & & \\
\hline
\end{tabular}

LOI loss of ignition

N.s.p parts non-soluble in $\mathrm{HCl}$ and $\mathrm{Na}_{2} \mathrm{CO}_{3}$

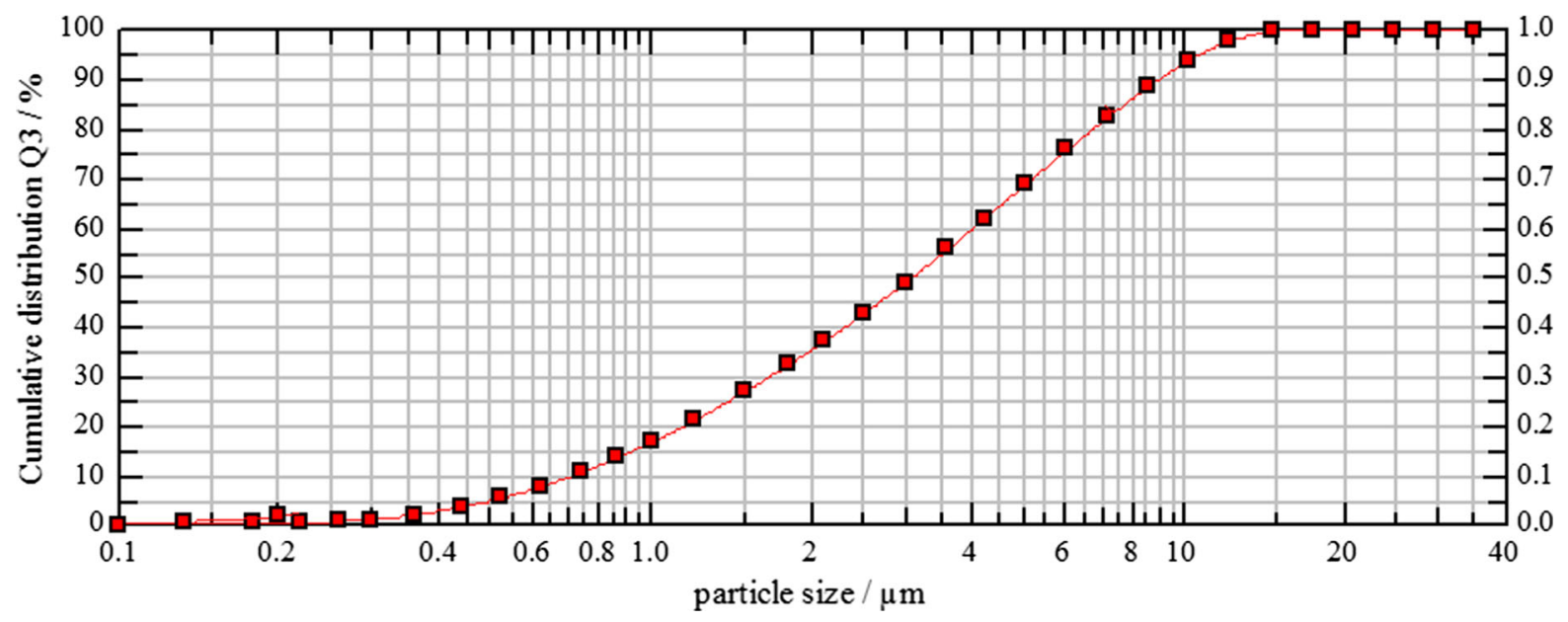

Fig. 1 Particle size distribution of meta-halloysite

Table 2 Opal aggregate composition

\begin{tabular}{llllllll}
\hline Constituent & Opal & Chalcedony & Quartz & Talc & Goethite & Pores & Sum \\
\hline Content [\%vol.] & 60 & 30 & 2 & 1.5 & 1 & 0.5 & 100 \\
\hline
\end{tabular}

Table 3 Mix proportion for mortar specimens

\begin{tabular}{llllll}
\hline \multirow{2}{*}{ Mixtures } & \multicolumn{2}{l}{ Cementitious material (\%-mass) } & & \multicolumn{2}{l}{ Fine aggregate (\%-mass) } \\
\cline { 2 - 3 } \cline { 5 - 6 } & Portland cement & Meta-halloysite & & Unreactive quartz sand & Opal aggregate \\
\hline 1 & 100 & 0 & 94 & 6 \\
3 & 95 & 5 & 94 & 6 \\
4 & 90 & 10 & 94 & 6 \\
5 & 85 & 15 & 94 & 6 \\
\hline
\end{tabular}

from the mortar without and with meta-halloysite (amount of 5, 10, 15 and 20\% by mass of cement). The aggregate-binder (cement + meta-halloysite) ratio was 2.25 and the w/b (water-binder) ratio was 0.5 . After $24 \mathrm{~h}$, the specimens were demoulded and stored in water at $80 \pm 2{ }^{\circ} \mathrm{C}$ for another $24 \mathrm{~h}$. Then the mortars were immersed in a $1 \mathrm{M} \mathrm{NaOH}$ solution at $80 \pm 2{ }^{\circ} \mathrm{C}$ for 28 days. The changes in the length of the specimens were measured using a Graff-Kaufman apparatus. The length measurements were made every day up to day 14 and then every 7 days. The expansion measurements were prolonged to 28 days, although the standard test only requires expansion measurement up to 14 days. According to the standard tests, mortar bars that expand less than $0.1 \%$ after 14 days of immersion are considered to be non-reactive. At the 
same time an expansion level between 0.10 and $0.20 \%$ indicates that aggregates have a potential to cause deleterious ASR in the field. In this case, another test should be performed. Expansion after 14 days more than $0.20 \%$ is considered to cause high risk of ASR deterioration.

\subsection{Thermo gravimetric analysis}

Calcium hydroxide content was evaluated using TGA on the pastes produced at $w / b$ ratio 0.5 . The thermal analysis was performed in the nitrogen environment using SDT Q600 thermogravimetric analyser. Specimens were tested from 20 to $1050{ }^{\circ} \mathrm{C}$ with the heating rate of $10{ }^{\circ} \mathrm{C} / \mathrm{min}$. After 3, 7, 14 and 28 days, pieces of up to $5 \mathrm{~g}$ in weight were taken from the core part of the specimens and crushed to pass the $0.063 \mathrm{~mm}$ sieve. The consumption of calcium hydroxide due to the pozzolanic reaction of meta-halloysite was determined based on TG decomposition profile of calcium hydroxide in the temperature range of $450-500{ }^{\circ} \mathrm{C}$ in the paste specimens with 0 and $20 \%$ meta-halloysite dosage.

\subsection{Scanning electron microscopy and energy dispersive X-ray spectral analysis}

The microstructural examination was performed on polished sections from mortar bars after 28 days of soaking in $1 \mathrm{M} \mathrm{NaOH}$. The SEM examination was conducted in back-scatter mode using NOVA NANO SEM200 (FEI EUROPE COMPANY) equipped with EDS analyser. The tests were performed on prepared polished sections from mortar bars without mineral addition and with $20 \%$ meta-halloysite dosage. The specimens were impregnated with the epoxy resin and polished mechanically. Carbon conductive coating was applied onto the specimens. The composition of ASR products and $\mathrm{C}-\mathrm{S}-\mathrm{H}$ phase was determined at a minimum of 20 measuring points $(18 \mathrm{keV})$.

\section{Results}

\subsection{Mortar expansion}

Figure 2 compares linear expansion of the mortars without addition (control mortars) and with metahalloysite. In each case, linear expansion of the mortar specimens prepared with reactive aggregate was reduced due to the addition of meta-halloysite. The results indicated a reduction in mortar expansion with an increase in mineral addition content. The 14-days expansion values of mortars with 5, 10, 15, 20\% metahalloysite had expansion reduced by approximately $12.3,64.4,82$ and $95.9 \%$ compared to control specimens. Only the replacement of $20 \%$ of the cement mass with meta-halloysite lowered the expansion to a safe level of not more than $0.1 \%$ at 14 days.

In compliance with ASTM C1567 specification, we can state that incorporation of meta-halloysite plays an important role in ASR mitigation in mortars with $6 \%$ reactive opal aggregate. After 14 days of storing the specimens in the $1 \mathrm{M} \mathrm{NaOH}$ solution, expansion increased in mortars both with and without metahalloysite. The 28-day expansion of mortar bars with $5,10,15,20 \%$ meta-halloysite decreased by approximately 4.7, 50.6, 68.2, 92.9\% compared to the control specimens. Ramlochan observed a similar trend in mortars with metakaolin, indicating that the cause might lie in insufficient amount of the mineral additive [28] and/or the decrease in $\mathrm{Al}$ in the pore solution, as suggested by Chappex and Scrivener [16]. Chappex and Scrivener's findings revealed that the ASR rate was strongly affected by the presence of aluminium in the pore solution. They indicated that the reduction of silica dissolution in the samples with SCMs was possibly most effective at a higher concentration of aluminium at early age and higher reserve in aluminium over time.

\subsection{Portlandite content}

Calcium hydroxide contents for control pastes and the pastes with 20\% meta-halloysite are shown in Fig. 3.

The amount of portlandite in the control cement paste increased during the cement hydration, reaching the highest value after 28 days. In the specimens with the addition of $20 \%$ meta-halloysite, the content of $\mathrm{Ca}(\mathrm{OH})_{2}$ after 28 days was $6.72 \%$. When comparing the percentage of free calcium hydroxide in specimens with the mineral addition, approx. $61.1 \%$ less $\mathrm{Ca}(\mathrm{OH})_{2}$ was detected. The decreased amount of portlandite indicates that meta-halloysite reacted with calcium hydroxide in a pozzolanic reaction. It needs to be noted that the differences in the portlandite content in the paste specimens with and without metahalloysite can be explained also by a combined effect 


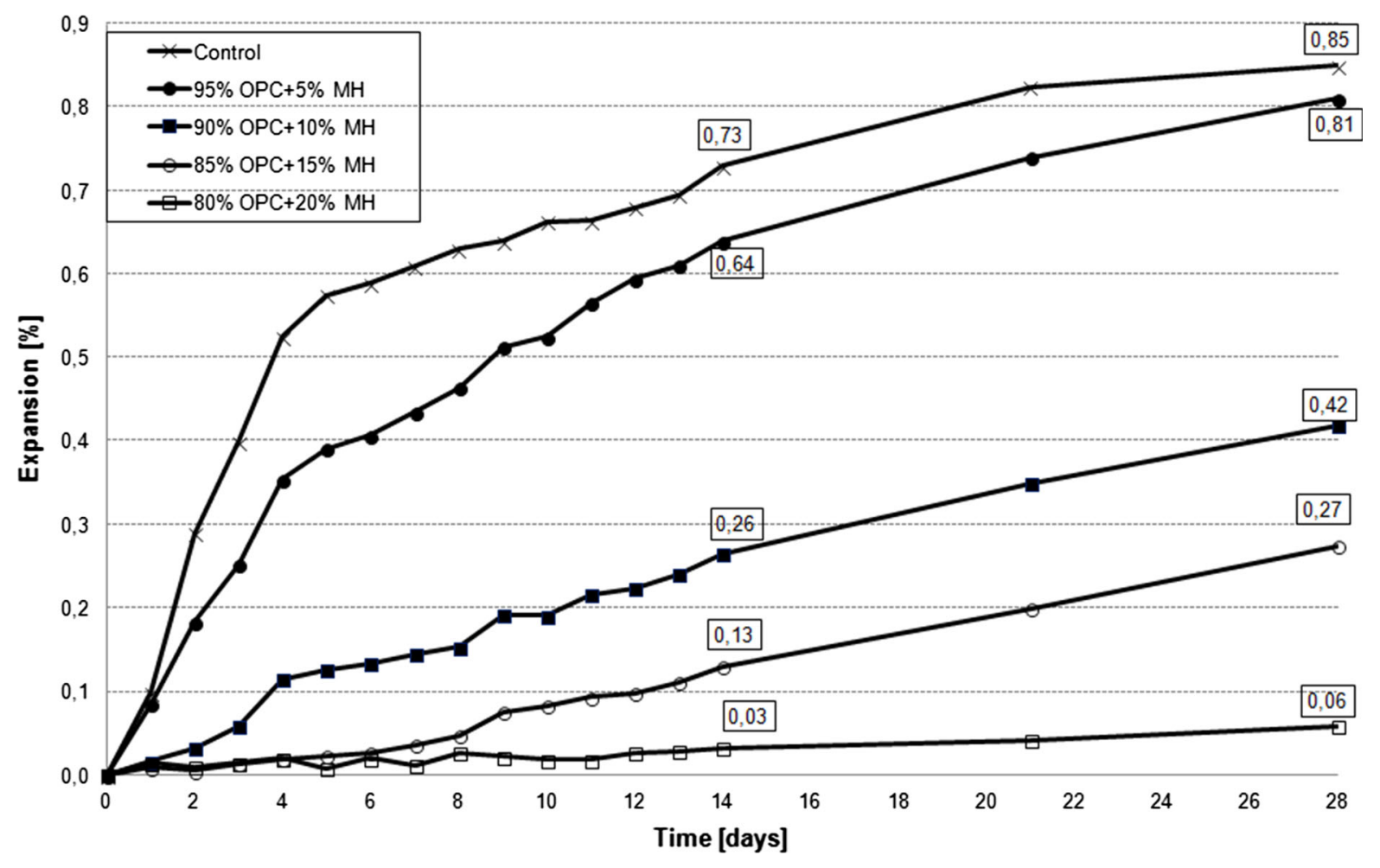

Fig. 2 Expansion of mortar bars containing meta-halloysite as a cement replacement

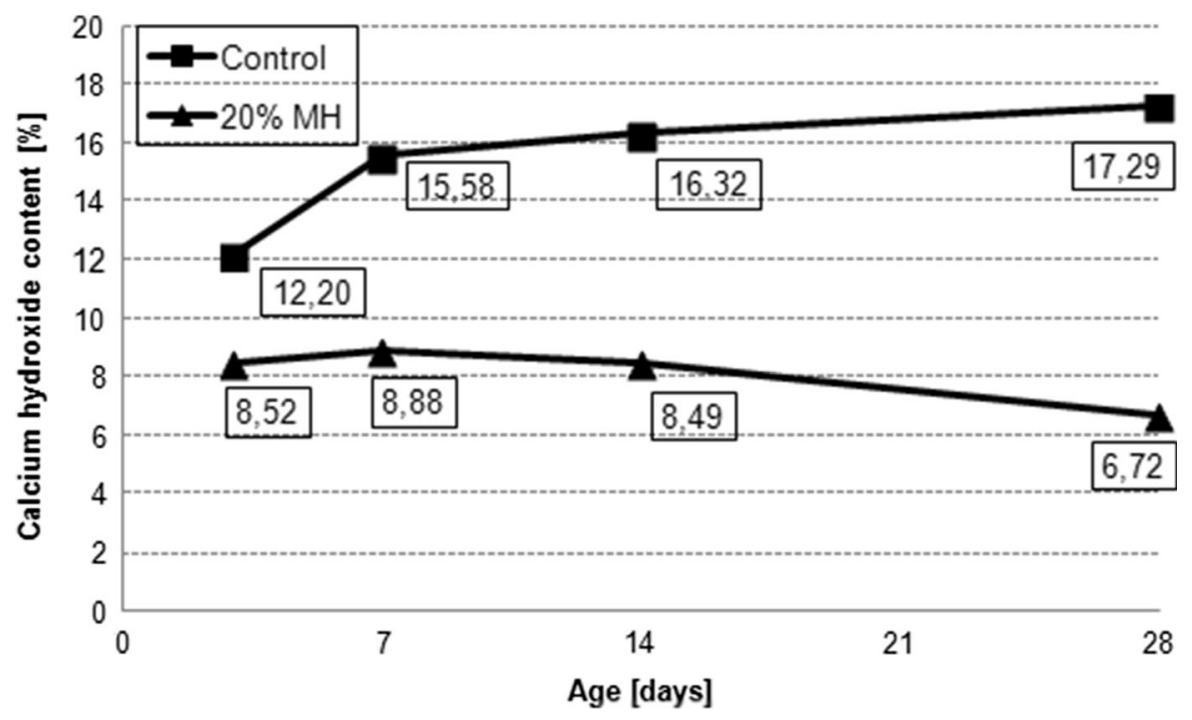

Fig. 3 Calcium hydroxide content as a function of time

of two simultaneous mechanisms: dilution effect and effect of reaction [12]. The total amount of calcium hydroxide produced by cement hydration is reduced due to cement replacement by mineral addition. Nevertheless, the presence of fine meta-halloysite may increase the amount of calcium hydroxide. 


\subsection{Mortar microstructure}

Microstructural images from a polished mortar section without mineral addition are shown in Fig. 4. A significance number of cracks was observed within the cement paste and aggregates. It can be observed that on the aggregate surfaces, in the interior of an opal aggregate and in air voids ASR gel was created (Fig. 4a-d). The ASR gel diffused into the surrounding cement paste. The gel located in the air void exhibits cracks induced drying shrinkage during sample preparation (Fig. 4b). These results are in agreement with the 28-day expansion value of control mortar bars.

The addition of 20 mass $\%$ meta-halloysite, which reduced mortar expansion substantially, failed to protect opal aggregate grains against the reaction with sodium and potassium hydroxides. However, in specimen with meta-halloysite only a minor amount of ASR gel was detected. As in the specimens without the addition, the gel was observed mostly at the surface of reactive aggregate, passing through a considerable part of the cement paste (Fig. 5a). Isolated gel deposits in the cement paste were also observed (Fig. 5b). Nevertheless, as is shown in Fig. 5c-d, the interfacial transition zone of aggregates with the cement matrix is dense. Possibly the aluminium interaction with reactive silica can lead to the formation of aluminosilicate on silica surfaces.

\subsection{C-S-H and ASR gel composition by SEM- EDX}

Figure 6a shows mean $\mathrm{Si} / \mathrm{Ca}$ and $\mathrm{Al} / \mathrm{Ca}$ atomic ratios in ASR gels observed in the control specimens and in those with meta-halloysite as analysed by EDS. The ASR gel composition is also shown as a function of $(\mathrm{Na}+\mathrm{K}) / \mathrm{Si}$ vs $\mathrm{Si} / \mathrm{Ca}$ in Fig. 6b. Compositions of the ASR products vary, largely due to the inhomogeneity of reactive aggregate grains, i.e., different grading and surface area. Additionally, the pore solution composition varies with time [29]. The content of individual ions in the reaction products was related to their location and stage of the ASR reaction. In this study, the ASR composition was determined at the surface of opal aggregate grains.

The $\mathrm{Si} / \mathrm{Ca}$ ratio of the gel formed around the reactive particle in the control specimen varied substantially within $0.55-3.40$ (Fig. 6a). The reaction products formed around the opal grains in the mortars containing meta-halloysite had higher values of the $\mathrm{Si} /$
Ca ratio, between 1.90 and 3.55 (Fig. 6a). The EDS analysis showed higher $(\mathrm{Na}+\mathrm{K}) / \mathrm{Si}$ ratio of ASR gel in the control mortar compared to that containing meta-halloysite (Fig. 6b). However, there was a considerable variation in the $(\mathrm{Na}+\mathrm{K}) / \mathrm{Si}$ ratio both in the gels of control specimens and of those with mineral addition, which might also depend on the location analysed. Analysis of the $\mathrm{Al} / \mathrm{Ca}$ ratios of the ASR gel in the specimens with meta-halloysite showed noticeably higher aluminium content compared to the specimens without the mineral addition (Fig. 6a). This was probably due to aluminium being incorporated in the ASR gel [16].

Compared with the control mortar, the $\mathrm{C}-\mathrm{S}-\mathrm{H}$ phase showed the reduced $\mathrm{Ca} / \mathrm{Si}$ ratio due to the addition of meta-halloysite, which improved its alkali binding capacity, as shown in Table 4. Considering that meta-halloysite is rich in alumina, the $\mathrm{C}-\mathrm{A}-\mathrm{S}-\mathrm{H}$ phase was also present. The $\mathrm{Al} / \mathrm{Ca}$ ratio increased from 0.07 in control specimens to 0.24 in those with $20 \%$ meta-halloysite.

\section{Discussion}

Adding meta-halloysite to mortars reduced ASRinduced expansion. The linear expansion of mortars decreased with increasing amount of the addition. The expansion in mortars prepared with meta-halloysite was $12.3-95.9 \%$ lower after 14 days and $4.7-92.9 \%$ after 28 days than that in the control specimens. The safe expansion level in the specimens, classified as non-destructive to concrete, was recorded for the mortars prepared with $20 \%$ addition of meta-halloysite. The minimum amount of meta-halloysite necessary to protect the mortars against negative effects of ASR is comparable to the minimum amount of metakaolin reported in the literature [28]. It was observed, however, that mortar bar storing conditions, as set out in ASTM C1567, i.e., at $80{ }^{\circ} \mathrm{C}$, immersed in $1 \mathrm{M} \mathrm{NaOH}$, may affect the final expansion. The analysis of the sediment taken from the containers used for sample storage showed the presence of aluminium hydroxide and sodium silicate, which are probably the products of the dissolution of the mineral addition. Additionally the presence of large amounts of alkalis from soak solution may reduce the ability of SCM to limit ASR expansion by exceeding their capacity to bind alkalis [30]. 


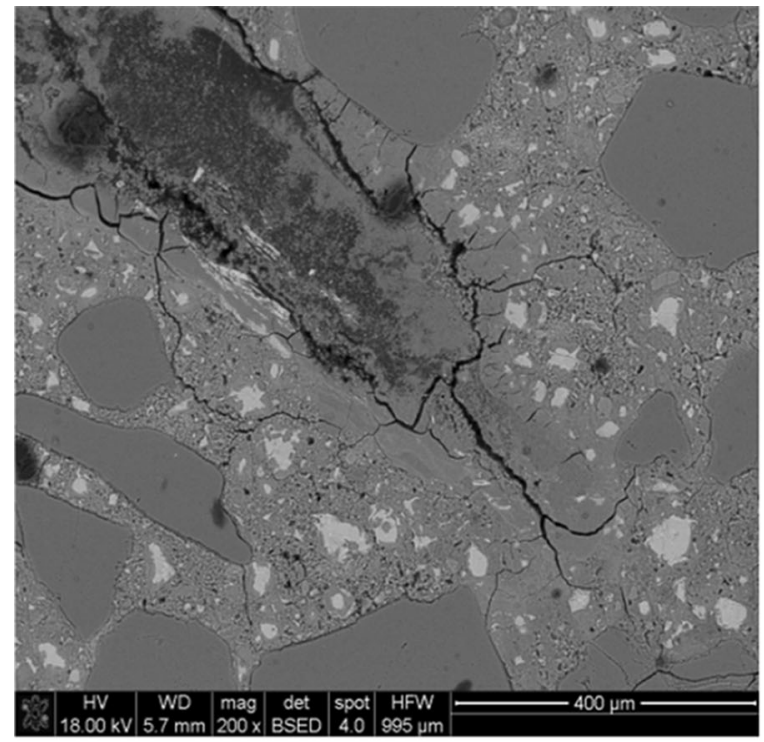

(a)

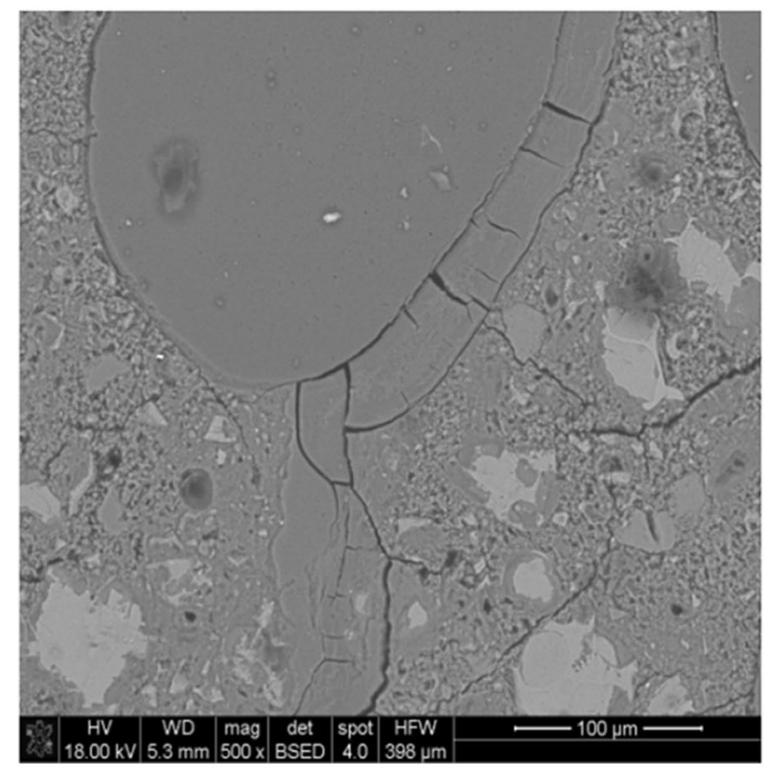

(c)

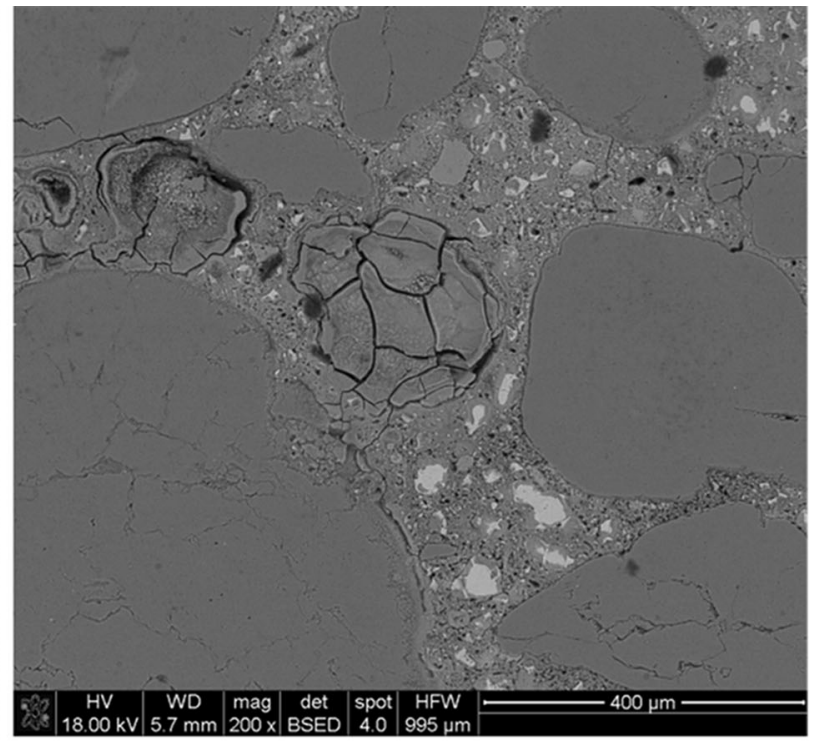

(b)

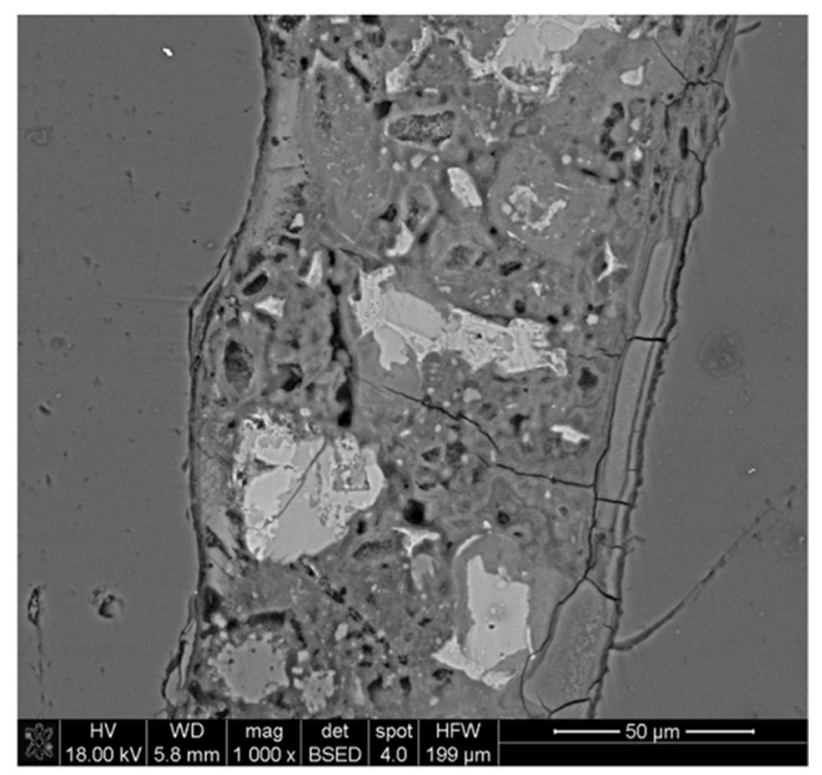

(d)

Fig. 4 SEM images of control specimens without meta-halloysite after 28-day immersion in $1 \mathrm{M} \mathrm{NaOH}$ (a) ASR gel within the cement paste and aggregate particle (b) ASR gel in air voids (c-d) ASR gel at the surface

One of the benefits associated with the use of pozzolans is a reduced $\mathrm{Ca}(\mathrm{OH})_{2}$ derived from the hydrolysis of silicate phase of cement clinkers in the cement matrix. The TG tests confirmed that metahalloysite is pozzolanic. The presence of calcium ions in the gel is widely thought to be necessary for the gel to have swelling properties [31].
The silicate ions from the meta-halloysite dissolution react with calcium and form the $\mathrm{C}-\mathrm{S}-\mathrm{H}$ phase of a low $\mathrm{Ca} / \mathrm{Si}$ ratio. It is commonly assumed that the increased $\mathrm{Si} / \mathrm{Ca}$ ratio in the $\mathrm{C}-\mathrm{S}-\mathrm{H}$ phase increases $\mathrm{Na}$ and $\mathrm{K}$ sorption capacity of $\mathrm{C}-\mathrm{S}-\mathrm{H}[20,32,33]$. The C$\mathrm{S}-\mathrm{H}$ phase in meta-halloysite specimen was able to bind more sodium in comparison with the $\mathrm{C}-\mathrm{S}-\mathrm{H}$ 


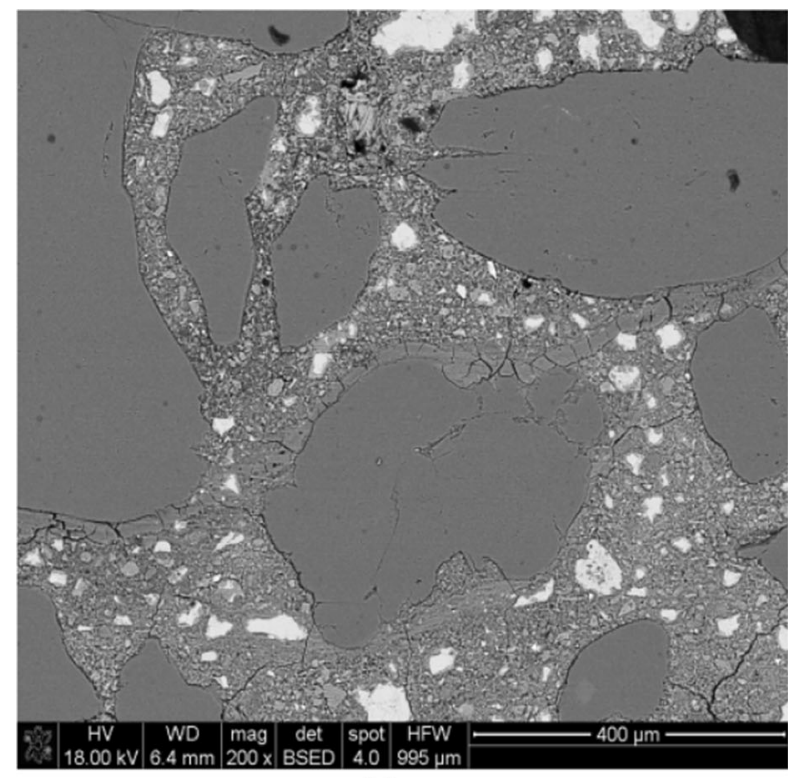

(a)

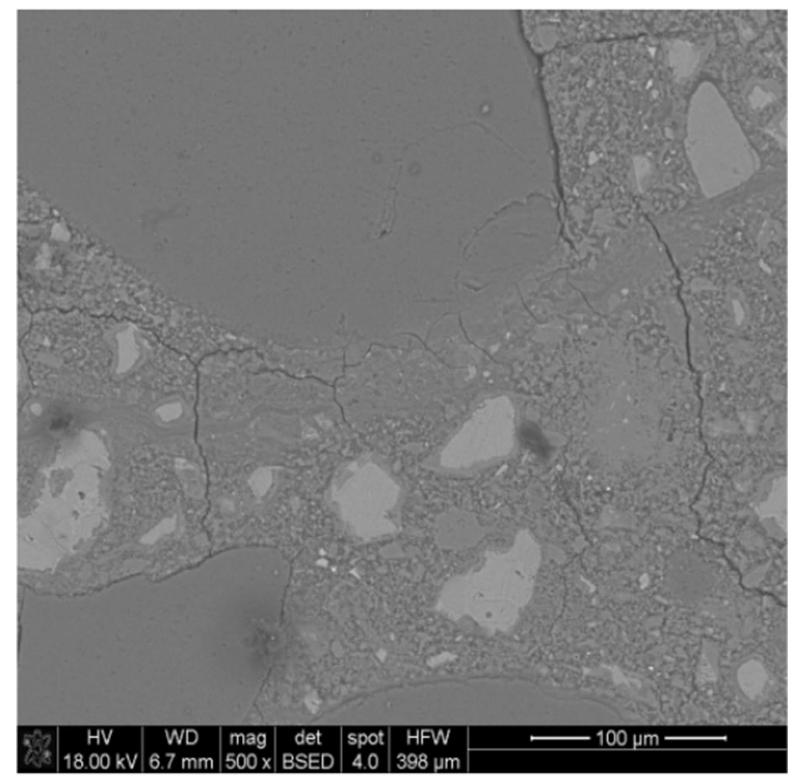

(c)

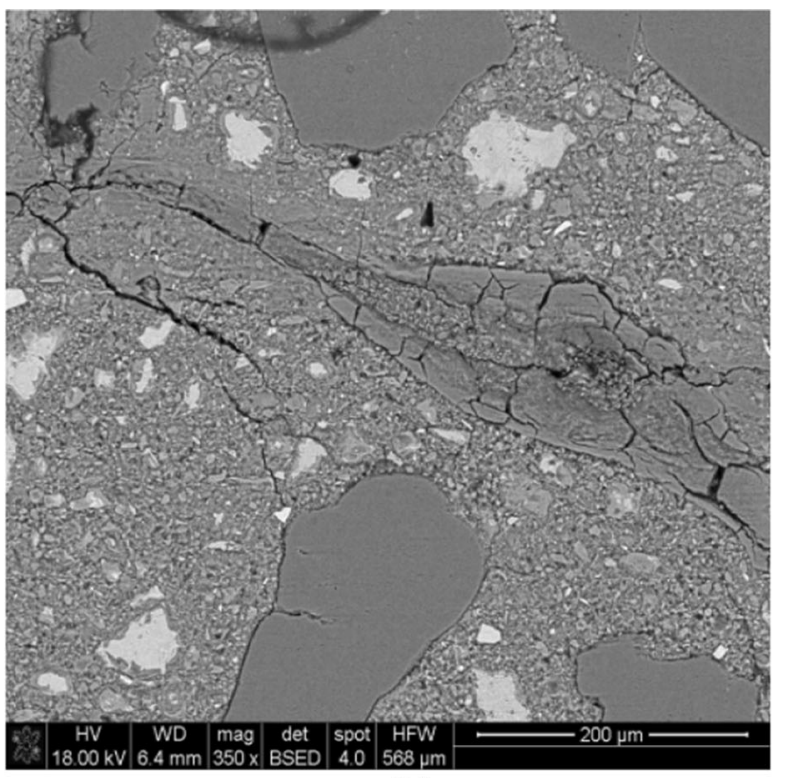

(b)

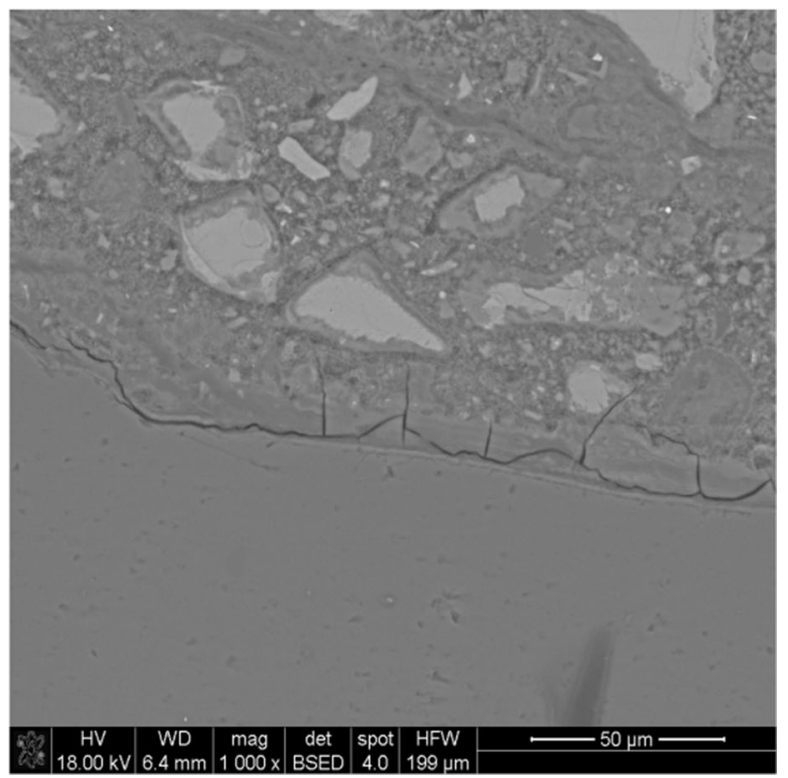

(d)

Fig. 5 SEM images of mortar with $20 \%$ addition of meta-halloysite (a) ASR gel formed around opal aggregate grains (b) massive gel in the cement matrix (c-d) interfacial transition zone of opal aggregate and cement paste

from the control specimen which suggests that this mineral can effectively mitigate ASR.

Additionally, the $\mathrm{C}-\mathrm{A}-\mathrm{S}-\mathrm{H}$ phase formed in the mortars prepared with meta-halloysite. As demonstrated by Chappex and Scrivener, the aluminium content $(\mathrm{Al} / \mathrm{Ca}=0.17$ in mortars with $15 \% \mathrm{MK})$ in the $\mathrm{C}-\mathrm{S}-\mathrm{H}$ phase with $\mathrm{Ca} / \mathrm{Si}$ ratio $=1.5$, which is close to that obtained by the author of this paper with $20 \% \mathrm{MH}$ $(\mathrm{Al} / \mathrm{Ca}=0.24)$, is likely to have little effect on the increase of alkali binding, compared with $\mathrm{C}-\mathrm{S}-\mathrm{H}$ in the control specimen [21]. However further research is required in this area.

$\mathrm{Al}^{3+}$ ions also affect silica solubility. Aluminium is adsorbed on the surface of $\mathrm{SiO}_{2}$ and probably 


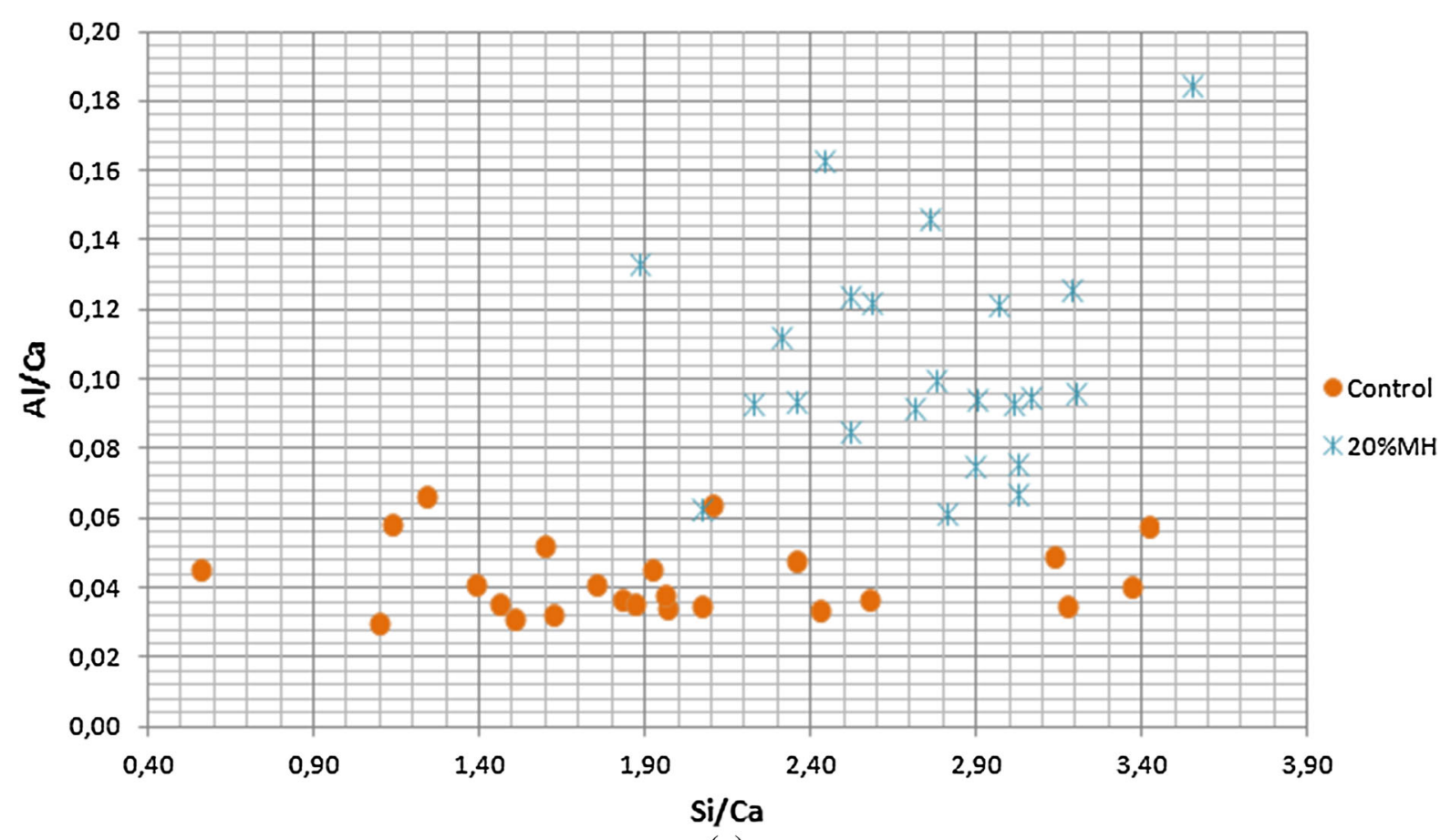

(a)

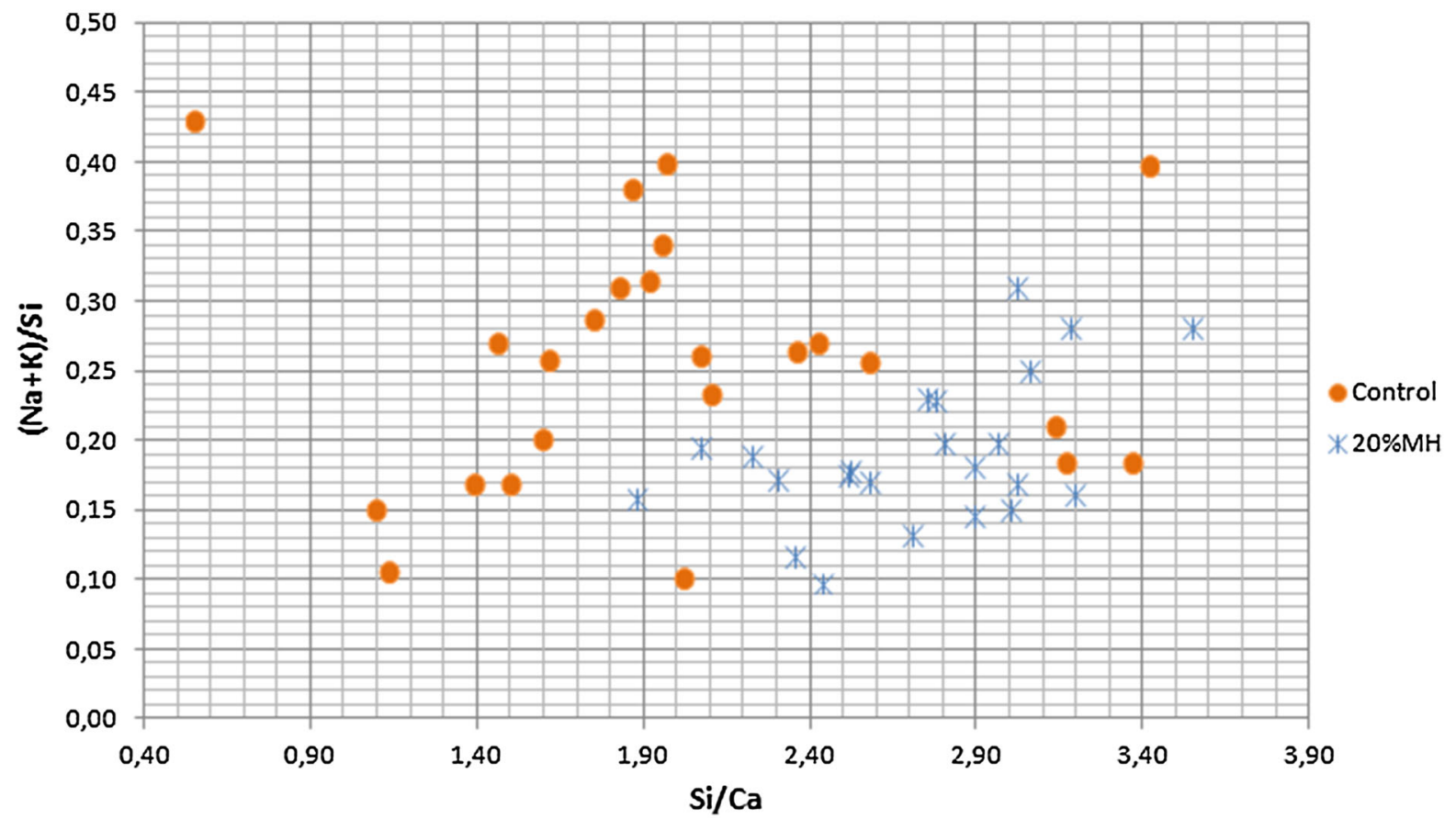

(b)

Fig. $6 \mathrm{Al} / \mathrm{Si}$ and $\mathrm{Si} / \mathrm{Ca}$ ratios $(\mathbf{a}), \mathrm{Si} / \mathrm{Ca}$ and $(\mathrm{Na}+\mathrm{K}) / \mathrm{Si}$ ratios $(\mathbf{b})$ in the ASR gel of the mortars at 28 days of immersion in a $1 \mathrm{M}$ $\mathrm{NaOH}$ solution 
Table 4 Average atomic composition of C-S-H gel measured by EDS

\begin{tabular}{lllllllll}
\hline & $\mathrm{Na}$ & $\mathrm{K}$ & $\mathrm{Ca}$ & $\mathrm{Si}$ & $\mathrm{Al}$ & $\mathrm{Ca} / \mathrm{Si}$ & $\mathrm{Na} / \mathrm{Si}$ & $\mathrm{Al} / \mathrm{Ca}$ \\
\hline Control & 2.51 & 0.45 & 21.50 & 10.01 & 1.54 & 2.15 & 0.25 & 0.07 \\
$20 \% \mathrm{MH}$ & 3.56 & 0.40 & 18.71 & 12.93 & 4.43 & 1.45 & 0.28 & 0.24 \\
\hline
\end{tabular}

incorporated in its structure [16, 34]. The solubility of the reactive silica is thus restrained, and the high content of $\mathrm{Al}_{2} \mathrm{O}_{3}$ present in the mineral additive additionally strengthen the inhibitive potential of aluminosilicate additives. In the case under analysis, the ASR gel in the mortars prepared with metahalloysite had an increased $\mathrm{Al} / \mathrm{Ca}$ ratio. Compared with the control mortars, the quantity of ASR products in the mortars prepared with meta-halloysite was smaller. The $(\mathrm{Na}+\mathrm{K}) / \mathrm{Si}$ atomic ratios of the ASR gels decreased only slightly compared to the control specimen. This indicates that aluminium ions in the meta-halloysite may limit the formation of gel by inhibiting silica solubility or forming a layer of aluminosilicate, hence smaller amounts of reaction products. This is reflected in the reduced expansion of the mortars being studied. The results obtained are consistent with the theory of Leemann [35].

\section{Conclusions}

This paper shows the results of investigations into the effect of meta-halloysite on the reaction between alkalis and reactive silica aggregate. The following conclusions can be formulated based on these results:

1. The use of meta-halloysite as partial replacement of Portland cement showed pozzolanic reactivity. A decreased $\mathrm{Ca}(\mathrm{OH})_{2}$ content indicating the consumption of portlandite by the pozzolanic reaction was detected,

2. Adding meta-halloysite to cement mortars resulted in reduced expansion caused by ASR. The expansion of the specimens after 14 days decreased by $12.3 \%$ in mortars prepared with $5 \%$ addition of meta-halloysite and $95.9 \%$ in those with $20 \%$ by mass replacement of cement by meta-halloysite,

3. Compared with the control mortars, the quantity of ASR products in the mortars prepared with meta-halloysite was smaller. Aluminium ions probably reduced the solubility of the silica. In both cases, though, the products were characteristic of ASR. Nevertheless, it was found that calcium-sodium-potassium silicate gels observed around aggregate grains in the mortars with $20 \%$ meta-halloysite had an increased $\mathrm{Al} / \mathrm{Ca}$ ratio. Probably aluminium interacted with silica producing aluminosilicate on the surface of reactive aggregate thus contributing to ASR inhibition. A slight decrease in $(\mathrm{Na}+\mathrm{K}) / \mathrm{Si}$ was observed in ASR gel from mortars with meta-halloysite, compared to control specimen,

4. The $\mathrm{C}-\mathrm{S}-\mathrm{H}$ phase in the mortars containing metahalloysite showed increased $\mathrm{Si} / \mathrm{Ca}$ and $\mathrm{Al} / \mathrm{Ca}$ ratios, which resulted in the improved sodium ion sorption capacity. The reduced content of calcium ions in the ASR gel of the mortars with meta-halloysite confirmed pozzolanic activity of meta-halloysite.

Acknowledgements The author wishes to acknowledge the financial support received from Ministry of Science and Higher Education Republic of Poland within the framework of Subject Subsidy for the Faculty of Civil Engineering and Architecture, Kielce University of Technology to maintain the research potential. Statutory activity MNSP.BKTO 17.005.

\section{Compliance with ethical standards}

Conflict of interest The author declares the absence of any conflict of interest.

Open Access This article is distributed under the terms of the Creative Commons Attribution 4.0 International License (http:// creativecommons.org/licenses/by/4.0/), which permits unrestricted use, distribution, and reproduction in any medium, provided you give appropriate credit to the original author(s) and the source, provide a link to the Creative Commons license, and indicate if changes were made.

\section{References}

1. Diamond S (1976) A review of alkali-silica reaction and expansion mechanisms 2. Reactive aggregates. Cem Concr Res 6:549-560. doi:10.1016/0008-8846(76)90083-1

2. Thomas MDA, Fournier B, Folliard KJ, Resendez YA (2011) Alkali-silica reactivity field identification handbook, No. FHWA-HIF-12-022 
3. Kawamura M, Fuwa H (2003) Effects of lithium salts on ASR gel composition and expansion of mortars. Cem Concr Res 33:913-919. doi:10.1016/S0008-8846(02)01092-X

4. Owsiak Z, Zapała-Sławeta J (2015) The lithium nitrate effect on the concrete expansion caused by alkali-silica reaction in concrete of gravel aggregate. Cem Lime Concr $82: 25-31$

5. Boddy AM, Hooton RD, Thomas MDA (2009) The effect of the silica content of silica fume on its ability to control alkali-silica reaction. Cem Concr Res 33:1263-1268. doi:10.1016/S0008-8846(03)00058-9

6. Liu TC, Li GH, Huang W, He XC, Jiang F, Zhang LS (2013) The study on metakaolin's effect of restraining the alkalisilica reaction of slate aggregate. Appl Mech Mater 357-360:732-736. doi:10.4028/www.scientific.net/AMM. 357-360.732

7. Hester D, McNally C, Richardson M (2005) A study of the influence of slag alkali level on the alkali-silica reactivity of slag concrete. Constr Build Mater 19(9):661-665. doi:10. 1016/j.conbuildmat.2005.02.016

8. Santos Silva A, Bettencourt Ribeiro A, Jalali S, Divet L (2007) The use of fly ash and metakaolin for the prevention of alkalisilica reaction and delayed ettringite formation in concrete. International RILEM workshop on performance based evaluation and indicators for concrete durability, pp 335-342

9. X-x Feng, N-q Feng, Han D (2003) Effect of the composite of natural zeolite and fly ash on alkali-silica reaction. J Wuhan Univ Technol Mater Sci Ed 18(4):93-96. doi:10. 1007/BF02838402

10. Owsiak Z, Czapik P (2014) Limitation of the effects at alkali-aggregate reaction in concrete by the addition of zeolite. Cem Lime Concr 19(3):152-157

11. Kawabata Y, Yamada K (2017) The mechanism of limited inhibition by fly ash on expansion due to alkali-silica reaction at the pessimum proportion. Cem Concr Res 92:1-15. doi:10.1016/j.cemconres.2016.11.002

12. Afshinnia K, Rangaraju PR (2015) Influence of fineness of ground recycled glass on mitigation of alkali-silica reaction in mortars. Constr Build Mater 81:257-267. doi:10.1016/j. conbuildmat.2015.02.041

13. Zheng K (2016) Pozzolanic reaction of glass powder and its role in controlling alkali silica reaction. Cem Concr Compos 67:30-38. doi:10.1016/j.cemconcomp.2015.12.008

14. Turanli L, Bektas F, Monteiro PJM (2003) Use of ground clay brick as a pozzolanic material to reduce the alkalisilica reaction. Cem Concr Res 33:1539-1542. doi:10.1016/ S0008-8846(03)00101-7

15. Zhihui L, Xianghui L, Min D, Zhongzi X, Fengyn W, Mingshu T (2008) A new mechanism of mineral admixture suppressing alkali-silica reaction. In: Broekmans MATM, Wigum BJ (eds) Proceedings of the international conference on alkali-aggregate reaction. Trondheim, Norway, p 226

16. Chappex T, Scrivener K (2012) The influence of aluminium on the dissolution of amorphous silica and its relation to alkali silica reaction. Cem Concr Res 42(12):1645-1649. doi:10.1016/j.cemconres.2012.09.009

17. Chappex T, Scrivener K (2013) The effect of aluminum in solution on the dissolution of amorphous silica and its relation to cementitious systems. J Am Ceram Soc 96(2):592-597. doi:10.1111/jace.12098
18. Brykov A, Anisimova A, Rozenkova N (2014) The mitigation of alkali-silica reactions by aluminum-bearing substances. J Mater Sci Appl 5:363-367. doi:10.4236/msa. 2014.56041

19. Hong S-Y, Glasser FP (2002) Alkali sorption by C-S-H and C-A-S-H gels: part II. Role of alumina. Cem Concr Res 32(7):1101-1111. doi:10.1016/S0008-8846(02)00753-6

20. L'Hôpitala E, Lothenbach B, Scrivenerc K, Kulik DA (2016) Alkali uptake in calcium alumina silicate hydrate (C-A-S-H). Cem Concr Res 85:122-136. doi:10.1016/j. cemconres.2016.03.009

21. Chappex T, Scrivener K (2012) Alkali fixation of C-S-H in blended cement pastes and its relation to alkali silica reaction. Cem Concr Res 42(8):1049-1054. doi:10.1016/j. cemconres.2012.03.010

22. Bach TTH, Chabas E, Pochard I, Cau Dit Coumes C, Haas J, Frizon F, Nonat A (2013) Retention of alkali ions by hydrated low-pH cements:mechanismand $\mathrm{Na}+/ \mathrm{K}+$ selectivity. Cem Concr Res 51:14-21. doi:10.1016/j.cemconres. 2013.04.010

23. Churchman GJ, Carr RM (1975) The definition and nomenclature of halloysites. Clay Clay Miner 23:38-388

24. Sand LB, Comer JJ (1955) A study in morphology by electron diffraction. Clay Clay Miner 3:26-30

25. Guggenheim S, Adams JM, Bain DC, Bergaya F, Brigatti MF, Drits FA, Formoso MLL, Galan E, Kogure T, Stanjek H (2006) Summary of recommendations of nomenclature committees relevant to clay mineralogy: report of the Association Internationale Pour L'etude des Argiles (AIPEA) nomenclature committee 2006. Clay Clay Miner 54:761-772

26. ASTM C1260 (2007) Standard Test Method for Potential Alkali Reactivity of Aggregates (Mortar-Bar Method). ASTM International, West Conshohocken, PA

27. ASTM C1567 (2007) Standard Test Method for Determining the Potential Alkali-Silica Reactivity of Combinations of Cementitious Materials and Aggregate (Accelerated Mortar-Bar Method). ASTM International, West Conshohocken, PA

28. Ramlochan T, Thomas M, Gruber K (2000) The effect of metakaolin on alkali-silica reaction in concrete. Cem Concr Res 30:339-344. doi:10.1016/S0008-8846(99)00261-6

29. Wang S (2015) Cofired biomass fly ashes in mortar: reduction of alkali silica Reaction (ASR) expansion, pore solution chemistry and the effects on compressive strength. Constr Build Mater 82:123-132. doi:10.1016/j. conbuildmat.2015.02.021

30. Johnson R, Shehata MH (2016) The efficacy of accelerated test methods to evaluate alkali silica reactivity of recycled concrete aggregates. Constr Build Mater 112:518-528. doi:10.1016/j.conbuildmat.2016.02.155

31. Thomas MDA (1998) The role of calcium in alkali-silica reaction. Materials Science of Concrete (Sidney Diamond Symposium), Am Ceram Soc Bull. Ohio, USA, pp 325-337, special volume

32. Hong S-Y, Glasser FP (1999) Alkali binding in cement paste: part I. The $\mathrm{C}-\mathrm{S}-\mathrm{H}$ phase. Cem Concr Res 29(12):1893-1903. doi:10.1016/S0008-8846(99)00187-8

33. Wang L, He Z, Cai X (2011) Characterization of pozzolanic reaction and its effect on the $\mathrm{C}-\mathrm{S}-\mathrm{H}$ gel in fly ash-cement 
paste. J Wuhan Univ Technol Mater Sci Ed 26:319. doi:10. 1007/s11595-011-0222-4

34. Bickmore BR, Nagy KL, Gray AK, Brinkerhoff AR (2006) The effect of $\mathrm{Al}(\mathrm{OH})_{4}^{-}$on the dissolution rate of quartz. Geochim Cosmochim Acta 70:290-305. doi:10.1016/j.gca. 2005.09.017
35. Leemann A, Bernard L, Alahrache S, Winnefeld F (2015) ASR prevention-effect of aluminium and lithium ions on the reaction products. Cem Concr Res 76:192-201. doi:10. 1016/j.cemconres.2015.06.002 